\title{
MARKET MODEL FOR MANAGEMENT OF PROFIT IN INDUSTRIAL ENTERPRISE
}

\author{
J. Angelova* \\ Department of Economics, Industrial Engineering and Management, Technical university of Sofia, \\ Bulgaria
}

\begin{abstract}
The purpose of the report is to presents a model for profit optimization and management, which takes into account both the quantity of sales, prices, costs and other factors, as well as new factors related to market and competitors - market share, prices, quality and marketing costs of competitors and others. There are listed features, limitations and advantages of the model. For more clarity, the presentation of the model is accompanied by two main types of tasks related to optimal prices, strategies and costs for the industrial enterprise.
\end{abstract}

Key words: Market segment; Quantity; Cost; Group of Factors.

\section{THE THEORETICAL ASPECT OF GOVERNANCE}

The functioning of industrial enterprises in market conditions poses the problem of managing the financial result. The new economic conditions require new methods of analyzing its management. Of course, when talking about a financial result, its positive value is taken into account because in the market economy the business activity has as its main purpose the obtaining of a positive financial result - profit. This is quite logical, since the realization of capital-free business is impossible, and profit is the main source of real capital increase and management. It is known that capital cannot be reproduced unless profit is gained from its use. For example, if economic activity takes place without profit, then the possibility of capital growth is reduced to zero. (1)

Then a simple production can be carried out in industrial enterprises, where the expansion of production is devoid of its surplus - the profit. It is in this sense that profit is treated as the main source of capital growth and expansion

*Correspondence to: Jordanka Angelova, Associate Professor, Department of Economics, Industrial Engineering and Management, Technical university of Sofia, Bulgaria,, jsa@tu-sofia.bg of industrial production. Profit is therefore the most important financial-valuation indicator for the business and the state of the industrial enterprise, as its value shows the effect of the production-economic activity. It is a basic prerequisite for the successful development of the industrial enterprise and, in its proper policy, it will undergo serious development in areas such as innovation, marketing, sales promotion and staffing, etc. In this connection, various methods are being developed and applied to study different dependencies on quantity, cost, cost, quality and other factors in order to optimize and improve the financial result.

Known methods for target earnings are based on sales, investments and assets. In sales, the price is set to provide a profit that represents a predetermined percentage of the sales volume. For investments, the price includes a target profit rate, which is defined as a percentage of the capital invested in the production. For assets, the price is determined on the basis of a target rate of profit on the total capital held by the enterprise.

\section{MARKET MODEL FOR ANALYSIS AND MANAGEMENT OF PROFIT}

This report presents a model in which profit is a function of prices, quantity, direct costs, 
marketing costs, market segment size, and the prices and quality of competing products, this is a market-oriented model for profit analysis. The scientific basis of the proposed model is the differential equation of sales, made up of F.Bass, V.Mahajan and E.Muller. (2) It represents the change of sales per unit of time depending on the amount of sales at any given time.

The model determines the economic profit that plays a key role in the business when adopting management decisions. In turn, the accounting profit determined on the basis of the enterprise's financial statements is of high informative value in the economy. It is of great importance to stock owners because it allows us to assess the state of the company and their investments.

The model defines the sales function, which allows for the set values of the independent variables / price and product quality, marketing costs, market marketing efficiency, market segment size, price and quality of competing products and initial sales volume / to determine the sales volume of the enterprise realized over a certain period of time. (Figure 1)

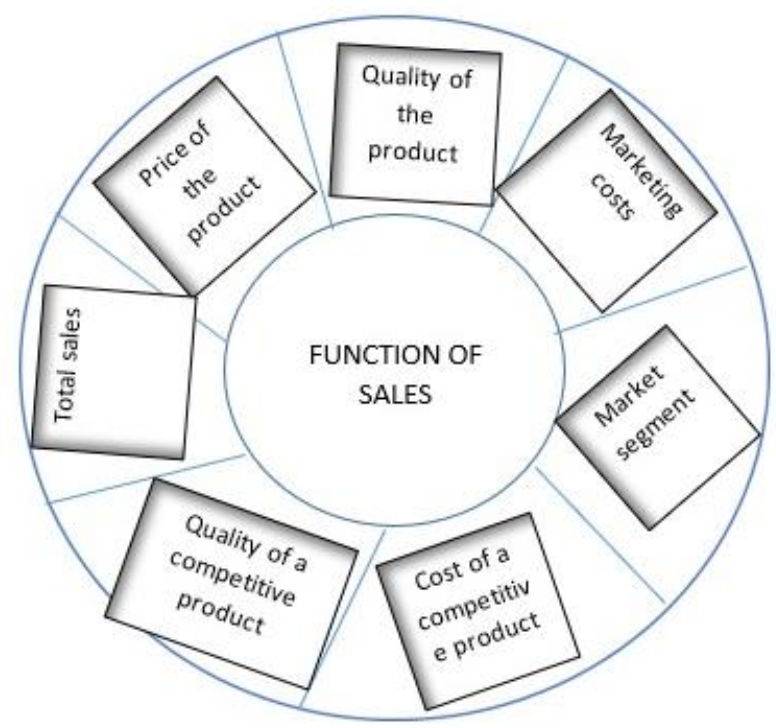

Figure 1. Model sales function for profit management

Profit is also determined after applying a particular integral for a period labeled O-T, i. from 0 to $\mathrm{T}$ (time), i. e. the time for which to plan. Sales projects are being developed during the planning period. Profit planning is important because profit is a basic base for every industrial enterprise. The determination of the profit is related to the determination of the volume of cash receipts. It is calculated by multiplying the planned natural volume of the marketed production by the sales prices in force at that time. The planned natural volume of the production to be realized is the same as the remainder of finished products at the beginning of the period, the volume of the planned production was added and the remainder of the unrealized output at the end of the year was subtracted.

The model has been developed for single-item and multi-product production. The following features are characteristic:

$>\quad$ It is assumed that the amount of sales at the start time is a constant value. Since a particular task is dealt with in a particular task, the time in each case is also considered to be a constant magnitude;

$>$ When compiling the model, competitors' production prices are assumed to be permanent, and if during the period in question some of the competitors change the price of their product, this change is reflected in the model and a new solution is adopted;

The quantitative assessment of the quality of the products can be determined using the most frequently method of mathematical distances or the method of expert assessments. The second method is most applicable because it is reliable enough and more accessible;

$>$ As a limitation, the production capacities of the basic machinery, equipment and equipment used are taken into account as, due to the influence of various causes / adjustment, loss of working time due to damage, lack of raw materials and materials, etc. I scientifically proved that the actual working fund time is assumed to be a random magnitude subject to Gaussian distribution. This is the distribution of the values that 
accumulate around the middle (so-called arithmetic mean) and is known as "normal" distribution;

A limiting condition of capital is that marketing costs should not exceed a certain marketing budget.

In its final form, the described model is a nonlinear model of mathematical programming based on differential equations, which takes into account the dynamics of the processes. The idea of the author of this paper is not to expose the mathematical apparatuses and formulas of the model but rather to point out some of its advantages for managing the profits of the industrial enterprise by:

1. With the introduction of market segment size, time and sales parameters at the start of time, it is possible to account for one variable affecting the profit, namely the market share of the industrial enterprise;

2. The model takes into account the decreasing effectiveness of marketing costs due to the difficult attraction of users through marketing tools;

3. The model and the mathematical apparatus and the use of differential equations reflect the change of sales per unit of time, which allows, depending on the selected integration limits, to maximize the profit for different periods of time. The importance of that advantage is due to the fact that, in general, the actions of the undertakings which maximize the profit for a given period of time may not lead to an optimum for another, longer or shorter period of time;

4. The practical application of the developed model is also important for the accuracy of the calculations. The accuracy achieved depends largely on the accuracy with which the differential equations describe changes in the sales of individual products.

5. Other factors that influence the accuracy of the model to a lesser extent are the precision of the regression analyzes of the differential equations and the accuracy of the numerical methods used. To obtain sufficiently accurate results, regression analyzes of differential equations need to be compiled on the basis of data between one and five years. This allows better seasonal fluctuations and better correlation coefficients.

In examining the areas of application of the profit management model, it can be stated that it allows to solve different tasks related to increasing the efficiency of the management of the industrial enterprise. For the sake of clarity, the model is concretized by presenting and solving two tasks: (1-3)

\section{First Task Type: Associated with setting optimal prices and marketing costs.}

The importance of this task stems from the fact that, in a market economy, pricing and marketing are decisive for the success of any industrial enterprise. In essence, the task is: to determine optimal product prices and marketing costs to maximize the enterprise's profit / profit / loss for a period of one year.

For this purpose, the product segments are marketed; the sales of the enterprise for the last month; weighted average prices of competing products; quantitative product quality assessments; the weighted average quality of competing products; the variable cost of production per unit of product, the number of machines and the processing times; the integral functions of distribution of the actual working time of machines and the monthly marketing budget. The decision gives prices and marketing costs that maximize profit.

Second Task Type: Associated with defining optimal strategies for market participants.

In particular, the task is to find the equilibrium prices and the marketing costs of the participants. These are the prices and marketing costs that one of the competitors changed and reduced their profits or, consequently, would increase their loss. The condition of the task is: size of the market segment; sales at the start time; variable unit costs; a factor that characterizes the effectiveness of marketing costs and product quality.

Therefore, when analyzing the financial result and above all the profit, account must be taken of the contradiction in the interests in the formation of different types of profits. There are two types of interest within the industrial enterprise:

- interests of managers;

- interests of the owners.

Managers seek to maximize gross and undistributed profits, as the higher level of these two categories gives them greater financial freedom to act in industrial management and decision-making, especially investment. The owners' interests are to maximize net profit as they receive dividends and also seek optimal levels of undistributed profit. The undistributed profits on the one hand provide a certain dividend but, on the other hand, limits the possibility of development, especially if it is too small. In 
some cases, there may also be interest in the amount of net profit if the staff receives part of the profit as an internal incentive, as is the case in some pay systems. But this is the subject of another development with another interpretation.

It is well known that there are different views on the determination and measurement of profit. Today, however, in the context of uncertainty and risk typical of the market economy, it is more than ever necessary for the manager and the owner to use the same approach when talking about profits. When it comes to profit, attention is usually directed to two groups of differences: (4-5)

- The difference between the value of sales and liabilities;

and

- The difference between revenue and expenditure.

In managing profits, the following questions can be reasonably asked: - How much profit is needed? - Is profit only the manager's sole motive when making management decisions? - What strategy should be followed when managers decide to maximize profits? The answer to these questions is related to the planning of the profit / financial plan, which is the basis for quality financial management. Without a well-developed plan, the financial manager cannot react quickly and can hardly be oriented in the market environment. Profit planning shows the ways in which it will be generated on the basis of a better level of production. It will show how persistent and variable costs and the magnitude of the debt will affect the stability of cash flows. In this respect, the financial manager must determine: - The time to be planned by designing sales plans during the planning period.
- On the basis of cash flow forecasting, the financial manager develops a profit plan for the quarter, year, and for five years.

As far as external interests are concerned, they are mainly from creditors and the state. Creditors are primarily interested in gross and undistributed profits, as the primary one is the first generation of a positive financial result, and second, a distribution that will ensure a timely and rhythmic repayment of the loans. The state is interested in both profit categories: gross and taxable. The explanation is that from the taxable profits of the industrial enterprise, the state will receive certain revenues and it has an interest in the taxable profit to be greater. It is for this that the state, with its normative documents, regulates the formation of the taxable profit.

It is a fact that interests in different profits are subject to regulation and management, and they need to be analyzed very carefully. Profit analysis should not be considered separately from strategic objectives and tactics. Because the strategic goal is of a lasting nature and presents the prospects of profiting for a longer period. It is clear that long-term profit-making goals will be linked to the marketing strategy and future markets of the organization.

Driving forces in forming marketing profits are: company strategy (binds profits to investment design and investment decisions). The tactical profit goal is formed by the commercial function and the operational management of sales. In this aspect of profit management, investment policy remains second-generation, with a focus on turnover and service factors. It is advisable to bear in mind that profit is under the influence of three groups of factors: (Table 1)

Table 1. A set of factors affecting profitability

\begin{tabular}{|l|l|l|l|}
\hline № & Group of factors & Meaning & Engagement \\
\hline 1. & Strategical & $\begin{array}{l}\text { Managerial Solutions. } \\
\text { Guarantee more than } \\
50 \% \text { of the profit. }\end{array}$ & $\begin{array}{l}\text { Business costs; Sales revenue; } \\
\text { Management of inventories of production, } \\
\text { work in progress and stock of material, } \\
\text { receivables from customers and others. }\end{array}$ \\
\hline 2. & National & $\begin{array}{l}\text { Related to state } \\
\text { regulatory policy }\end{array}$ & $\begin{array}{l}\text { They are expressed through increases and } \\
\text { decreases in taxable profits. }\end{array}$ \\
\hline 3. & In-company & $\begin{array}{l}\text { Associated with the } \\
\text { influence of the owners. }\end{array}$ & $\begin{array}{l}\text { This factor affects the seizure of part of } \\
\text { the profits by the owners in the form of } \\
\text { dividends. }\end{array}$ \\
\hline
\end{tabular}

Therefore, cost reduction is an important factor for profit growth. The costs of producing and realizing output determine the level and structure of the cost of the product, and hence the profits of a product. Efficiency is another factor for increasing profits, both in terms of 
increasing labor productivity, utilization of material resources, and increasing the financial resources used for this efficiency. Efficiency in this area requires a rigorous financial policy on the part of the managers of an enterprise. The overall efficiency is important:

- labor productivity;

- the degree of utilization of the production capacity;

- strict credit policy;

- fighting uncollectible debts;

- optimization of cash, etc.
It should be concluded that economic profit is a concept used to motivate managerial decisions in the industrial enterprise and is defined as the difference between revenue and total costs explicit and implicit. Based on this, it is necessary to investigate the efficiency of the entity through management. And to get the expected positive results for managers, they need to have enough credible and qualitative information about business goals, creativity, innovation, and good ideas to turn into practical developments to deliver high added value products and services value. (Figure 2)

\section{CONCLUSION}

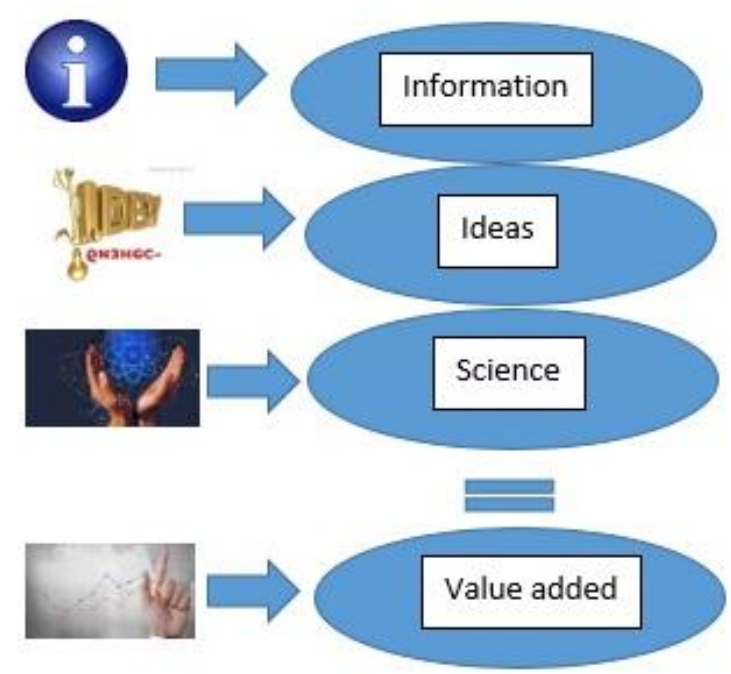

Figure 2. Effectiveness of the management of the industrial enterprise

Managers need to build a true conception of the main factors of profit. For example, timely release from inventory of finished goods is necessary by accelerating sales. For this purpose, the manager needs to make the following decisions:

- Looking for new markets;

- Reduce product prices;

- Make barter deals.

Finally, it can be noted that for the practical application of the model, an algorithm has been developed that includes three groups of activities: - providing the necessary information / quantities sold, prices, costs, quality, etc. /,

- Determination of the coefficients and dependencies / integral functions of distribution of the available working time fund, regression analysis of the differential equations, efficiency of the marketing costs.

- compiling and solving the model of the specific task / describing the functions of the profit for the individual products, defining the restrictive conditions of the model, compiling the model's target function, modeling and analysis of the results obtained.

\section{REFERENCES}

1. Donchev, D., J.Jekov, Pazarno-orientiran model za optimizirane na pechalbata pri upravlenie na predpriatieto, S., Proceeding, 2003.

2. R. Peres, E. Muller, and V. Mahajan, "Innovation diffusion and new product growth models: a critical review and research directions," International Journal of Research in Marketing, vol. 27, no. 2. View at Publisher · View at Google Scholar · View at Scopus, pp. 91-106, 2010.

3. V. Mahajan, E. Muller, and F. Bass, "New product diffusion models in marketing: a review and directions for research," Journal of Marketing, vol. 54, pp. 1-26, 1990. View at Google Scholarp The Scientific World Journal, Article ID 167481, 9 pages, Volume 2015http://dx.doi.org/10.1155/2015/1 67481, Research Article.

4. Zhineng Hu, Wei Lu and Bing Han, A TwoStage Method to Determine Optimal Product Sampling considering Dynamic Potential Market, The Scientific World Journal Volume 2015, Research Article.

5. https://www.bg-ikonomika.com/2010/10/4_ 26.html 